\title{
EXPERIENCES OF SEDIMENT TRANSPORT RESEARCH
}

Dániel Koch ${ }^{1}$

László Tamás Vas ${ }^{2}$

Enikő Anna Tamás ${ }^{3}$

UDK: 556.047(439)

DOI: 10.14415/konferencijaGFS2014.094

Summary: The Institute of Hydraulic engineering and Water management of Eötvös József College (Baja, Hungary) has been involved in the research of fluvial sediment transport processes for more than 10 years. The importance of sediment investigations is nowadays much underlined by the Water Framework Directive of the EU. But sediment measurements are different in different countries of Europe, and even inside Hungary. Sediment sampling was hardly systhematic in the past, and most of the sampling campaigns did not follow hydrological processes. Our main goal is to systhematize and methodologically develop sediment sampling and analysis, in order to supply suitable datasets to state-of-the art hydro-dynamical and transport modeling.

Keywords: Sediment, suspended load, bed load, sampling, analysis

\section{INTRODUCTION}

The Institute of Hydraulic engineering and Water management of Eötvös József College (Baja, Hungary) has been involved in the research of fluvial sediment transport processes for more than 10 years. The importance of sediment investigations is nowadays much underlined by the Water Framework Directive of the EU (60/2000/EC), because there is a requirement to continuously monitor morphological processes in order to help determine changes in the status of waterbodies [TAMÁS 2005].

After the genesis of the sediment, the water - as a transporting medium- whirls it, and it's moving raises a several complicated inter-related problems. On the upper section of a river (which have a large slope), there is enough energy to snatch the sediment up. Thus the bed load is specific on the upper section of the rivers. On the middle and the lower section the rate of the bed load is getting lesser, while the rate of suspended load is getting higher [GRAF 2000]. During the movement of the sediment the fragmenting of it

\footnotetext{
${ }^{1}$ Dániel, Koch, Water management technician, Eötvös József College, Institute for Hydraulic engineering and Water management, Bajcsy-Zs. u. 14., Baja, Hungary. tel: +36 79523900 113, e-mail: koch.daniel@ejf.hu

${ }^{2}$ László Tamás, Vas, Water management technician, Eötvös József College, Institute for Hydraulic engineering and Water management, Bajcsy-Zs. u. 14., Baja, Hungary. tel: +36 79523900 116, e - mail: vaslaszlo1991@gmail.com

${ }^{3}$ Enikő Anna, Tamás, Civil engineer, Eur.Ing., PhD., director of Institute, associate professor, Eötvös József College, Institute for Hydraulic engineering and Water management, Bajcsy-Zs. u. 14., Baja, Hungary. tel: +36 79523900 114, e - mail: tamas.eniko@ejf.hu
} 
is discernible. In Hungary most of the rivers have middle sections. The bed of these rivers are partially meandering. At these sections the methods of the river regulation is: flood controlling and cutting through the overdeveloped bends. This methods have a consequence of raising slopes. The raising slopes raise the sediment-transporting capacity too. The river doesn't snatch the sediment on the upper section, thus the river snatches up the missing sediment from the bed. This phenomenon erodates the bed. At the types of beds we must calculate with the reducing of the bed. At the case flood, we can observe reducing beds and silting floodplain because of the anthropogenic effects. The silting of the floodplains endangers the good ecological state as those getting under the water with higher and higher water-level. For the engineers, because of these reasons the samplings of sediment and processing at the laboratory is very important.

\section{METHODS}

Sediment measurements are different in different countries in Europe [SCHWARZ ET AL. 2008]. Methodologies and samplers are different, both in the field and during laboratory analysis as well. Even in Hungary, sampling and laboratory techniques have changed several times in the past. Also, sediment sampling was never really systhematic, and the sampling campaigns did not follow the hydrological processes [TAMÁS 2008]. That is how sediment data can hardly be compared; and the data series are inhomogeneous and they cannot be statistically analysed. The majority of the existing sediment data in Hungary are not suitable for the data supply needs of state-of-the-art numerical modeling. It is even problematic to describe the connections between water flow (discharge) and sediment transport, because data are scarce and irregular. Even the modern sampling methods (Acoustic Doppler Current Profiler [ADCP],Laser In Situ Scattering and Transmissometry [LISST]) need calibration. Under the calibration we understand sampling and processing. For these reasons we need appropriate (both for quantity and quality) sampling of sediment.

\section{Fieldwork}

We have collected sediment samples in relation to three sampling campaigns in frame of two projects:

- DANUBE EHT 2010 IPA CBC HU-SRB/0901/221/001

- 350 suspended load samples, 70 bed material samples

- TÁMOP 4.2.2.B-10/1-2012-0032 Tudományos képzés mühelyeinek támogatása az Eötvös József Főiskolán (Scientific training at EJF)

- 75 suspended load samples, 10 bed-load samples, 10 bed material samples

In our work, we collected bathymetry and free-surface elevation data along the entire reach with bathymetry surveyed along transect lines set 100 meters apart, and freesurface elevations measured at every river kilometer [TAMÁS ET AL. 2012]. At the same time, detailed measurements were carried out at cross-sections $1 \mathrm{~km}$ apart. The measurements taken at each of the cross-sections included: the ADCP (Acoustic Dopler Current Profiler) flow discharge measurements along multiple transects from a moving

\section{4 | JOURNAL OF FACULTY OF CIVIL ENGINEERING (2014)|}


vessel, followed by simultaneous flow velocity measurements and sediment and sampling at each of the data verticals. The simultaneous measurements and the sampling along each of the verticals included the ADCP measurement of the three flow velocity components carried out from a stationary vessel. The collected samples were processed in the laboratory to provide selected sediment and water-quality parameters.

\section{Sampling methods}

The sampling of suspended sediment:

- sampling it in a cross-section of a river

- In a cross-section sampling in several (5-7-9) verticals

- In a vertical sampling in several (5-10) depths

Each of the depths we were collecting point-samples.

The pump-sampler is applicable if during the measurement the distance between the water-level and the suction side of the pump doesn't exceed the suction lift of the pump. The velocity can't be more than $1,8 \mathrm{~m} / \mathrm{s}$ and the depth has to be over $1,0 \mathrm{~m}$. The sampling must be at the speed and discharge that the velocity of the inflowing water is the same as the velocity of the river. The pressure side has to be parallel with the current.

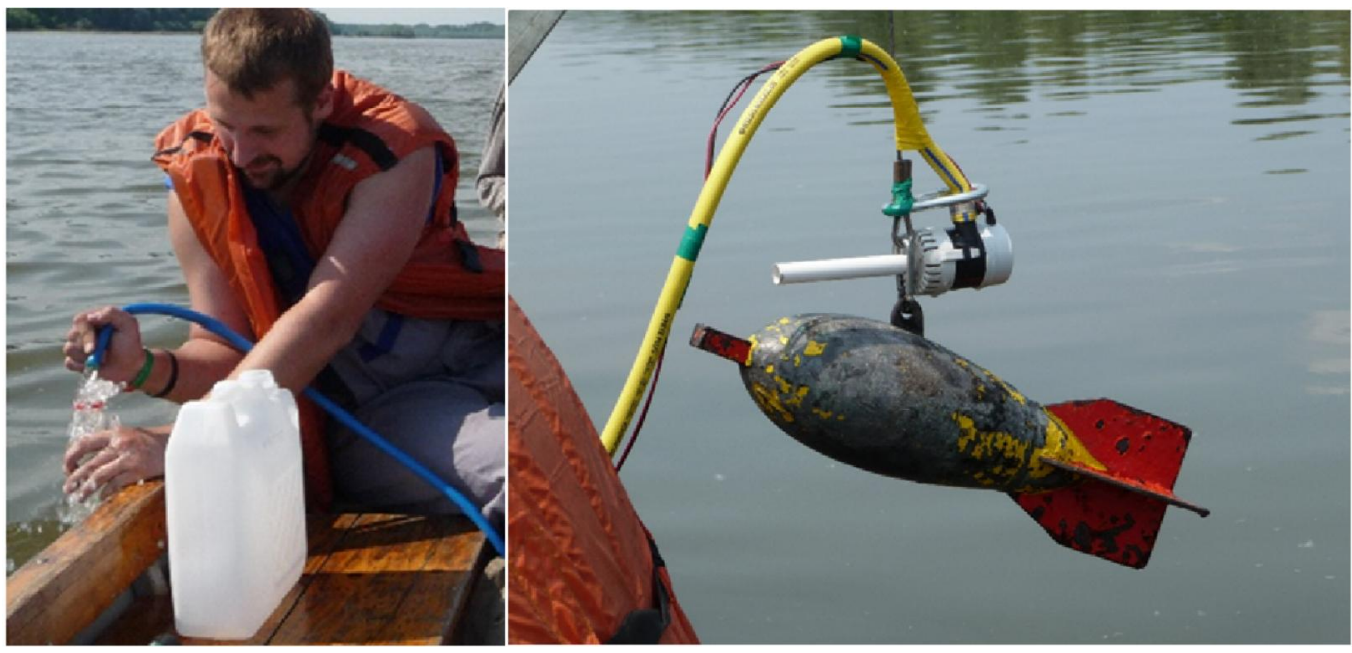

Suspended load sampling with pump (Danube, Mohács)

The bed load is moving intermittently on the bed, beacuse of the permanently changing sliding force. The bed load samplers disturbe the currents, thus they have an effect on the moving bed load. During the choosing of the sampler we have to minimalize the disturbance.

The sampling of the bed load usually happens with the Helley-Smith sampler or an another version of it. The equipment has different gap for each type of river. The gap depends on the grainsize and the mass flow of the sediment.

Falling over of the sampler is a frequent mistake. Usually a big gravel stuck under the sampler, thus the sediment flows under the sampler. 
For the elimination of this mistake, usually a camera is fixed in front of the sampler, which is recording it's opening. There is a screen on the boat, where we can observe the sampling and the disturbing effects.

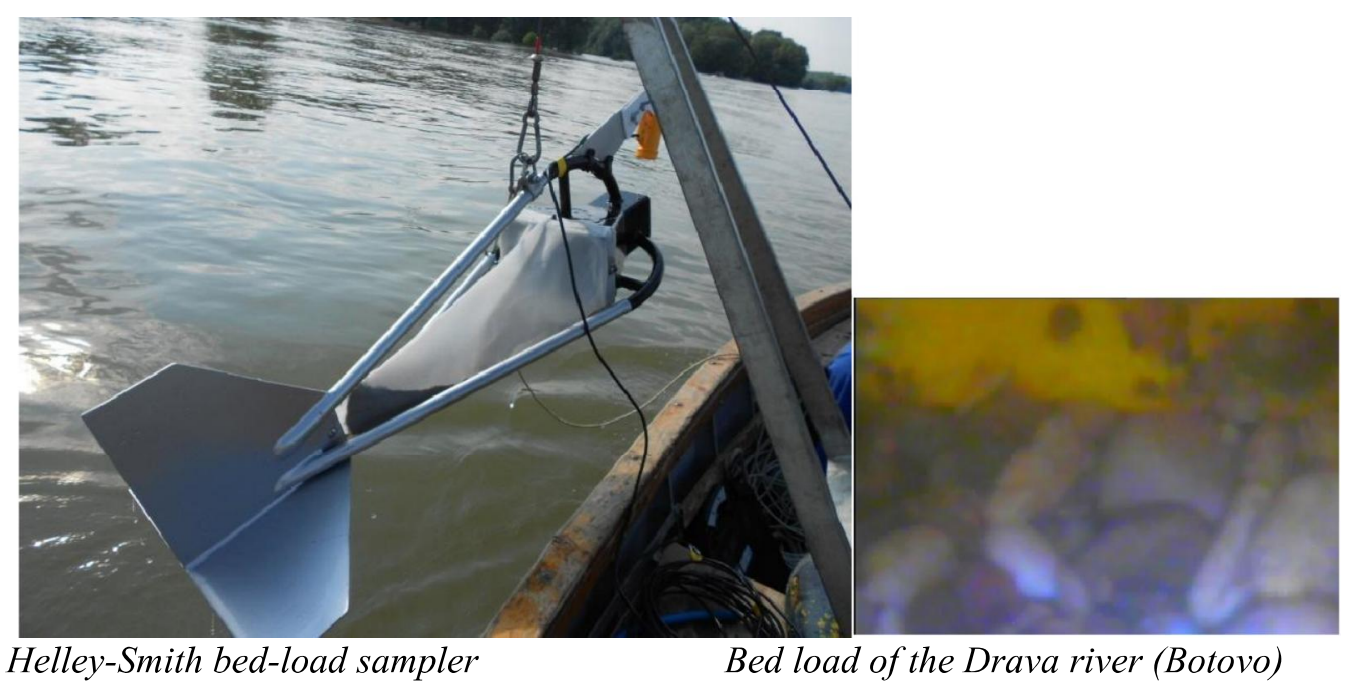

Often because of the big depth or the high velocity we can't sample the bed load. In this case we ought to sample the bed material. The grain-distribution of the bed material we can conclude the type of the bed material. We can collect samples both of them because they are completing each others' results.

We sampling the bed material with a bucket-sampler. Circle-profiled opening is for sleazy beds. For armoured beds, the opening of the sampler has to be sharped. The sharped sampler is digging into armoured beds.

\section{Bucket samplers (picture: DDVIZIG)}
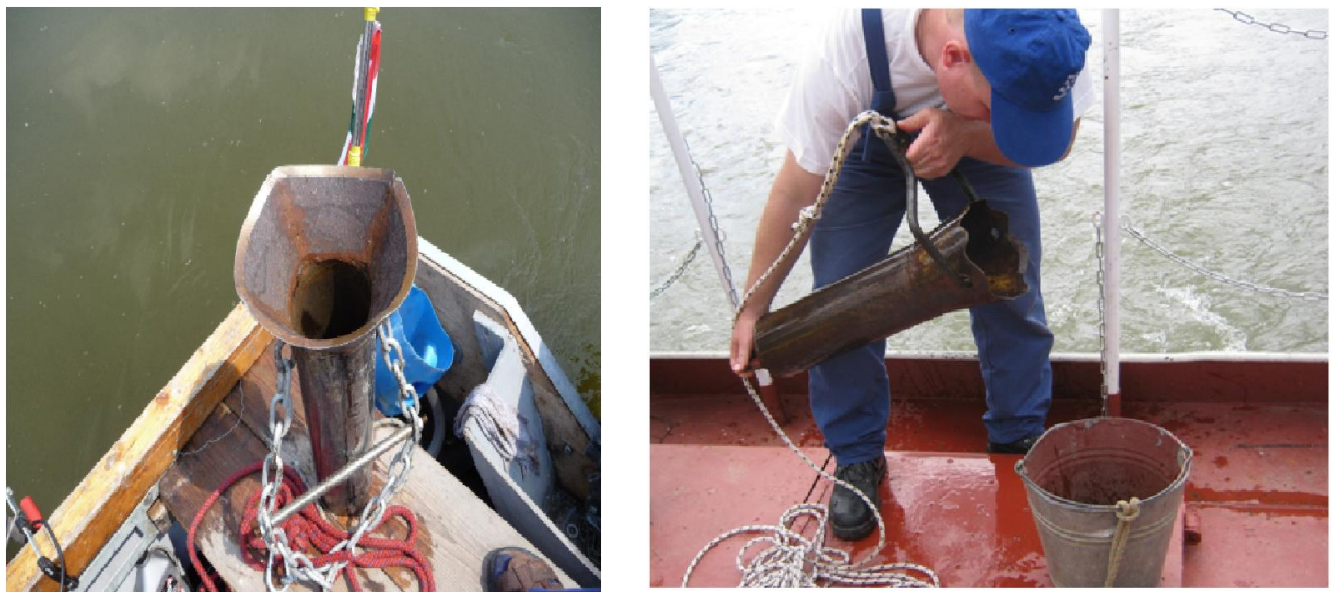

Experiments to measure suspended sediments with laser method: 


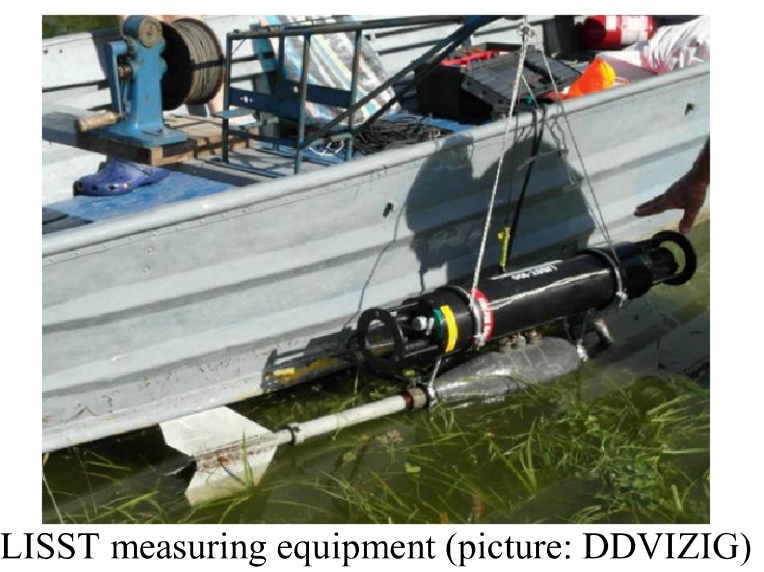

The Institute of Hydraulic engineering and Water management of the Budapest University of Technology and Economics used to make some testing and authenticating measurement with LISST-100 in the IPA project called Dráva morphological monitoring.

\section{Processing of the sediment samples}

In addition to the samples we collected ourselves, we also carried out the laboratory analyses of further two sample sets:

- Dráva morphological monitoring IPA CBC HU-HR/1001/112/0009

- 125db suspended sediment sample, $75 \mathrm{db}$ bed load sample, $75 \mathrm{db}$ bed sample

- "MORE" project

- 175db suspended sediment sample, $35 \mathrm{db}$ bed load sample, $35 \mathrm{db}$ bed sample

During the processing of the bed samples and the bed load samples, we dried the samples at $105^{\circ} \mathrm{C}$, until a constant weight. We measured their weight then we separate each fractions with a sieve. If the residue of the sieving is more than $10 \%$, we have to elutriate it.

After a 24 hours elutriation we decant the water from the suspended sediment. We measure the volume of the removed water. After we measured the volume of the rest water on the suspended sediment, we wash it to a glass-bowl. After a 24 hours drying, we measure the weight of the sediment. Dividing the weight of the sediment with the volume of the water we receive the concentration of the suspended sediment. We put the sediment with known weight into an aluminium-porringer with $0,65 \mathrm{~m} / \mathrm{m} \% \mathrm{NH}_{4} \mathrm{OH}$. This reagent promotes anti-coagulation. We store the samples in this reagent for 24 hours. Then after we separate the fractions by sedimentation. We perform the sedimentation in a modified Atterberg-type tubular elutriator. We pour the samples into a vertical glass-cylinder, which is filled with $\mathrm{NH}_{4} \mathrm{OH}$. We measured the temperature of the $\mathrm{NH}_{4} \mathrm{OH}$, so we know the sedimentation time of each fractions. In these times we 
depress the elutriated sediment into some glass-bowl. The weights of each fractions is measureable after drying. With this elutriater we can separate 6 fractions.

\section{EXPERIENCES}

- The concentration of the suspended sediment changes in a broad interval: $0,01-$ $0,3 \mathrm{~g} / 1$

- For the accurate measuring an analytical balance is necessary (measuring until $230 \mathrm{~g}$ with $0,00001 \mathrm{~g}$ accuracy)

- The elutriator demands precise treatment and big attention

- Drying and measuring the samples twice is lowering the accuracy

- Measuring the samples after drying is complicated, because of the sticking of the sediment. This is lowering the accuracy too.

- Raising the volume of the samples makes the accuracy better, but with the volume, the weight is raising too.

- Defining adequate mass flow curves needs more samples from different hydrological environment.

- A few sample is not appropriate for the modern data needs. The few samples is not suitable for the calibration of modern tools (ADCP, LISST). They aren't suitable for using at complicated hydrodinamical modells.

\section{OPPORTUNITIES OF DEVELOPMENT}

The development is for lowering the investigation-time and the human-resources needed. The planned innovation activity is for developing an existing technology and using it in practice. The existing technology is a sedimentation analysis, in which we collecting the elutriating suspended sediment in a dial, while we measuring the raise of its weight. From the collected data we can define the grain size distribution without collecting, drying and measuring subsamples.

During the development we have to define the parameters of components, the accuracy required and the technique of reaching it. We have to make a measuring set and its method of operation, and the documentation of it. Using the sedimentation balance we can avoid the drying and measuring for two times, which is increasing the mistake. The losses also increasing the mistake.

During the sampling, we done simultaneous ADCP measuring with no moving boat for assign the sample with its velocity vector. This will be a chance to calibrate the ADCP. The ViSea DAS PDT program is appropriate for finding link between ADCP data (from the reflected strenght of signal of a cell) and suspended sediment concentration. At the same time using the program is slightly complicated. It doesn't separate the calibration and the measuring methods. This program is good at showing the result at $3 \mathrm{D}$, but the subresults can't exportable.

The LISST is expensive and can measure in a narrow interval. But with this tools we can measure the grain size distribution and the concentration in-situ. Because of this, this tool needs a lot of concentration and grain size distribution for its calibration.

\section{8} | JOURNAL OF FACULTY OF CIVIL ENGINEERING (2014) | 
40

Међународна конференција

Савремена достигнућа у грађевинарству 24.-25. април 2014. Суботица, СРБИЈА

\section{REFERENCES}

[1] Bogárdi J. (1978): Sediment transport in alluvial streams., Akademiai Kiado, Budapest, Hungary, p.826, 1974.

[2] Graf W.H. (2000): Hydraulique Fluviale - Écoulement et phénomènes de transports dans les canaux à géométrie simple, vol. 16, Lausanne, Suisse, Presses Polytechniques et Universitaires Romandes.

[3] Rákóczi L., Szlávik L., Sziebert J., Tamás E.A., Süveggyártó A.M., Koch G. (2012) Sediment analysis study under the project of "Dráva morphological monitoring" REFERENCE: HUHR/1001/1.1.2/0009. Research report. 2012.

[4] Schwarz U., Babic-Mladenovic M., Bondar C., Gergov G., Holubova K., Modev S., Rákóczi L., Rast G., Steindl J., Sorin T., Tamás E.A. (2008): Assessment of the balance and management of sediments of the Danube waterway: Current status, problems and recommendations for action. Working paper for the Danube River Basin. pp. 1-60.

[5] Sziebert J. (2011.): Lebegtetett hordalékhozam mérés tapasztalatai ADCP-vel (előadás - Magyar Hidrológiai Társaság - XXIX. Vándorgyülés, Eger)

[6] Tamás E. A. (2003): Hullámtéri morfológiai folyamatok vizsgálata, különös tekintettel a hordaléklerakódásra. - Kutatások az Eötvös József Főiskolán, 3: 81-97.

[7] Tamás E. A. (2005.): Morfológiai célállapot-meghatározás kérdései és lehetőségei a magyarországi alsó Duna-szakaszon . - Kutatások az Eötvös József Főiskolán, 5: 255-262.

[8] Tamás E.A. (2008): Változások a Duna hordalékszállításában és annak vizsgálatában. KUTATÁSOK AZ EÖTVÖS JÓZSEF FÖISKOLÁN 2008:(8) pp. 119-128.

[9] Tamás E.A., Varga A., Sziebert J., Mátrai I., Lengyel Varga A., Spasojević M. (2012): The Danube River simultaneous bathymetric, flow, sediment and water quality data collection. In: Marko Ivetić, Radomir Kapor, Jasna Plavšić (ed.) 16th Conference SDHI and SDH, Donji Milanovac, Szerbia, 2012.10.22-2012.10.23. University of Belgrade, Faculty of Civil Engineering. pp. 204-216.

[10] Tamás E.A., Varga A., Sziebert J., Varga Gy., Koch D. (2013): A Vén-Duna mellékág vízszállításának és hordalékviszonyainak vizsgálata: 15 évvel az élőhelyrekonstrukciós célú részleges megnyitás után. In: Szlávik Lajos, Kling Zoltán, Szigeti Edit (ed.). XXXI. Országos Vándorgyülés : Magyar Hidrológiai Társaság. Gödöllö, Magyarország, 2013.07.03-2013.07.05. Budapest: Magyar Hidrológiai Társaság 